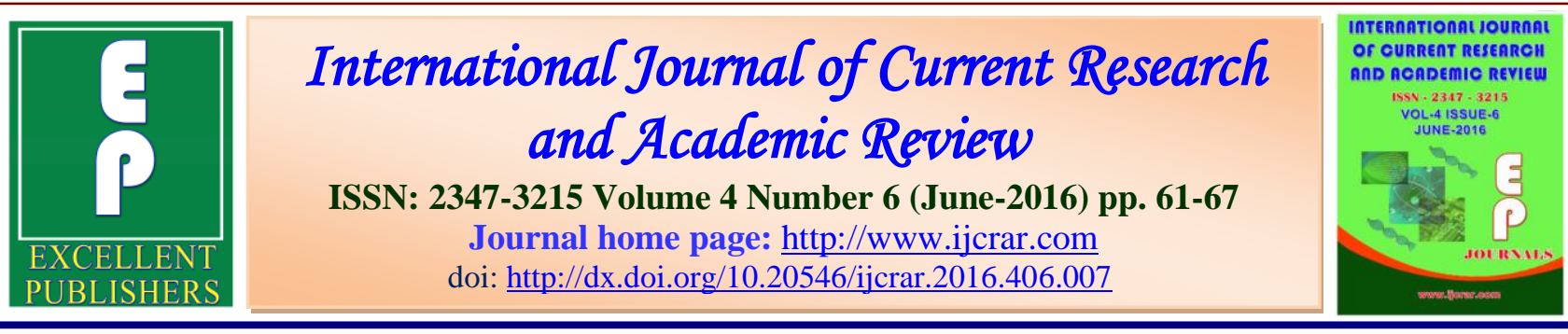

\title{
Impact of Mid Day Meal on Nutritional Status of School Going Children with Special Emphasis on Zinc
}

Iram Khan* and Sangeeta Pandey

Department of Nutrition and Dietetics, Mount Carmel College, No.58, Palace Road, Bangalore -560052 , Karnataka, India

*Corresponding author

KEYWORDS

Mid day meal

(MDM),

Non mid day meal

(NMDM),

Zinc deficiency,

Under-nutrition,

RDA.
A B S T R A C T

Mid day meal programme was introduced in India to protect child from class room hunger, increasing enrolment and attendance in the schools. It includes provision of lunch free of cost to school-children on all working days. Zinc deficiency is widespread and affects the health and well-being of populations worldwide. (i) To assess the nutritional contribution of mid day meal to the dietary zinc intake in school children (ii) to compare the prevalence of zinc deficiency between the children consuming MDM and NMDM school children. A total of 100 study subjects were randomly selected from two schools. Zinc and nutritional assessment was done using anthropometric measurements and 24 hours diet recall. Majority of study subjects (54\%) in mid day meal school and also majority (54\%) in non mid day meal school belonged to 11-12 years age group. Among 8-9 and 9-10 years of age 100\% subjects were having low $\mathrm{BMI}<18.5$. The mean intakes of all macronutrients and micronutrients were found to be lower than the RDA. A significant difference $(p<0.05)$ were found in zinc intake between mid day meal and non mid day meal subjects belonging to $10-12$ years age group. The nutritional contribution of mid day meal to dietary zinc was lower than the RDA (89mg).

\section{Introduction}

School children constitute a major segment of the community whose health and nutritional status will indicate the changing trend of nutritional profile of the region. Zinc is an essential trace element and has a number of roles and functions in the human body. This was proved in 1963 by determining zinc to be essential for human growth. Similarly later in 1974 the National
Academy of Sciences declared zinc to be an essential element for humans and established a recommended daily allowance. Then in 1990's there was increasing attention on the role of zinc deficiency in childhood morbidity and mortality in developing countries. The significance of zinc in humans and its deficiency leading health issues led to conduct this present 
study. In particular the study focuses on the nutritional status assessing the zinc intake of the children consuming mid day meal. Mid day meal program (MDM) was initiated by the central government of India to reduce the number of dropouts, enhance school enrolment, student attendance, student retention and improve nutritional status of children. In a study conducted on 6-12 years old school children it was seen that stunting and malnutrition was reduced after mid day meal introduction in the schools (Minj et al., 2014). Since mid day meal program proves to be beneficial and provides $1 / 3$ nutritional requirement of the children in a day, dietary assessment of zinc in mid day meal is important.

\section{Methodology}

A comparative study using random sampling method was conducted. Total 100 subjects were screened for zinc status. Two schools were selected for the study on the basis of consuming mid day meal and not consuming mid day meal (NMDM). In each school study subject were in the age group of 8-12 years. A pre-structured questionnaire was used to collect the general information, anthropometry measurements, mid day meal information and three days 24 hours diet recall. The weight and height was measured and recorded to assess the nutritional status of the study samples and compared to WHO (2007) standards.

\section{Results and Discussion}

The age wise distribution of the study subjects shows that the majority of the subjects (54\%) belonged to age 11-12 years, followed by $22 \%$ of subjects in 10-11 years age group and only $12 \%$ within $8-9$ years range in mid day meal school. Among non mid day meal school $54 \%$ of the study subjects were in 11-12 years age group, 24\% in $9-10$ age group and only $18 \%$ in $8-9$ years
(Table 1). In a study carried on 6-12 years of children to assess the prevalence of zinc deficiency and to study the association of zinc deficiency with anthropometric measurements and socio-demographic variables, in eastern Nepal reveals that prevalence of zinc deficiency was observed in 6-8 years old children when compared with 10-12 years children (Nepal et al., 2014).

Gender classification shows varying results with $64 \%$ females and $32 \%$ of males in MDM school whereas in NMDM School there were $64 \%$ of males and only $32 \%$ of females (Table 2). Study done on stunting and zinc deficiency among primary school children among rural area of Jiangsu Province reveals that boys had higher zinc deficiency than girls, whereas the prevalence of anemia in boys was lower than that in girls. The study shows that zinc deficiency and stunting were not highly prevalent among school children in rural regions with low soil zinc concentrations of Jiangsu Province (Yu Qin et al., 2008).

An increasing trend was observed in the mean heights as the age increases (Table 3), with the maximum mean height of 142.2 $( \pm 6.79)$ for $11-12$ years and minimum mean height being $124.2( \pm 2.5)$ for $8-9$ years in NMDM school. Similar increasing trend was found under MDM school subjects also, maximum mean height for 11-12 years was $134.7( \pm 3.56)$ and minimum mean height for 8-9 years was $115.5( \pm 12.45)$. These result was found to be significant $(\mathrm{p}>0.05)$ in the height of the subjects belong to the age group 11-12 years.

In a study conducted to analyze if $10 \mathrm{mg}$ zinc supplemental dose is appropriate for the children and does it have any interactions with copper and iron concentrations in the body. The results show that $\mathrm{Z}$ score for initial height-for-age was $<-1.3$. Significant 
change in plasma zinc concentration was observed in relation with zinc dose $(\mathrm{P}$ value $=0.001)$. Incidence of diarrhoea was decreased by $3 \mathrm{mg}$ zinc sulphate per day supplemental dose. No other dose response was noticed in the study subjects. Adverse effects on $10 \mathrm{mg}$ zinc supplements per day on copper and iron status was nil (Wuehler et al., 2008).

The table (Table-4) depicts the weight for age of the respondents. The mean weight of the study subjects were found in ascending order in both the schools. The maximum mean weight was seen in 11-12 years subjects with $34.42( \pm 4.76)$ and 32.35 $( \pm 7.40)$ in $\mathrm{MDM}$ and NMDM schools respectively. Minimum mean weight was found in 8-9 years study subjects with 19 $( \pm 3.03)$ in MDM school and $22.5( \pm 3.10)$ in NMDM school.

Several studies on effect of zinc supplementation on children's growth and development have been performed. Each study represent varying results, some studies show that zinc supplementation in higher doses can help and in some studies supplementation is of no benefit. Calculated mean reflects that there is a highly significant effect of zinc supplementation on height and weight increments, but no significant effect of zinc on (weight-forheight) indexes was found (Brown et al., 2006).

The study population was classified as underweight, normal weight, over weight and obese based on their BMI-for-age percentile (WHO, 2007). From the figure it is evident that cent-percent of the subjects in age group 8-9 and 9-10 years were in the underweight category, while $66.6 \%$ in the age group 10-11 were underweight, followed by $50 \%$ subjects in 11-12 years were also underweight. It was found that $3.7 \%$ study subjects in 11-12 years were falling under overweight category (Figure 1). In another study the extent of under nutrition at district level and the socioeconomic determinants of underweight children were assessed. On basis on BMI calculation it was seen that prevalence of under nutrition varied among districts of west Bengal. The percentages of underweight children were more in rural areas among Muslim families with illiterate parents and low standard of living. But in some other districts with lower middle economic status the prevalence of underweight was lesser. Thus it was found that the characteristics like religion, parents' educational status and standard of living index showed significant effect on the children's weights (Bharati et al., 2010).

In a study conducted to determine whether school or nonschool environments contribute more to childhood overweight, Comparison between children's gains in body mass index (BMI) when school is in session (during the kindergarten and firstgrade school years) with their gains in BMI when school is out (during summer vacation) was made. The results shown were that growth in BMI was typically faster and more variable during summer vacation than during the kindergarten and first-grade school years (Hippel et al., 2007).

The macronutrient consumption pattern among 8-10 years old study subjects reveals that mean energy, protein and carbohydrate consumed was fulfilling the requirements as given by the RDA. The mean energy intake was $1355 \mathrm{kcal} / \mathrm{d} \quad(\mathrm{RDA}=1690 \mathrm{kcal} / \mathrm{d})$, followed by mean protein consumption was $18.1 \mathrm{~g} / \mathrm{d} \quad(\mathrm{RDA}=29.5 \mathrm{~g} / \mathrm{d})$ and mean carbohydrate intake $172.1 \mathrm{~g} / \mathrm{d}(\mathrm{RDA}=253.5$ $\mathrm{g} / \mathrm{d}$ ) in MDM school subjects. In 8-10 years NMDM school subject's intake of energy, protein and carbohydrate was higher than MDM school subjects. The means of macronutrients were as follows: energy 
$1682.2 \mathrm{kcal} / \mathrm{d}( \pm 314.7)$, protein $24.7 \mathrm{~g} / \mathrm{d}$ $( \pm 3.3)$ and carbohydrate $197.3 \mathrm{~g} / \mathrm{d}( \pm 29.8)$. In both the school subjects fat consumed was found on borderline $(29.9 \mathrm{~g} / \mathrm{d}$ in MDM school) and (29.6g/d in NMDM school) as compared with RDA $(30 \mathrm{~g} / \mathrm{d})$. It is known that fat should be consumed in limited amount due to its association with several health risk factors. Significant differences were seen between both the schools macronutrient intake $(\mathrm{p}<0.05)$ (Table 5).

It was found that mean iron intake $3.57 \mathrm{mg} / \mathrm{d}$ and mean zinc $3.25 \mathrm{mg} / \mathrm{d}$ is lower among MDM school subjects. In NMDM school subjects mean iron intake $4.81 \mathrm{mg} / \mathrm{d}$ and mean zinc consumed was $4.05 \mathrm{mg} / \mathrm{d}$ was higher than MDM school subjects. Though the micronutrient intake was higher in NMDM school subjects, it was observed that consumption pattern was not meeting the RDA (Iron-21mg/d and zinc- $8 \mathrm{mg} / \mathrm{d}$ ). Statistically significant difference was found in iron intake $\mathrm{t}=5.29(\mathrm{p}<0.05)$ (Table 5).

Micronutrients play a central part in metabolism and in the maintenance of tissue function. An adequate intake therefore is necessary, but provision of excess supplements to people who do not need them may be harmful. Single micronutrient deficiency states are comparatively easily recognized and treated (Shenkin, 2006).

The micronutrient status and its relationship with nutritional status in preschool children was assessed in a study including 340 preschool children. Deficiencies of zinc and vitamin A occurred among $67 \%$ and $38 \%$ of children, respectively. In the surveyed population, zinc deficiency was high and to a lesser degree vitamin A deficiency and vitamin D insufficiency prevailed. The nutritional status of the children was related to vitamin D status and with hemoglobin status. Zinc and vitamin A levels were low in children with severe stunting. Vitamins A, D and zinc levels were associated with haemoglobin status (Marasinghe et al., 2015).

Analyzing the intake of macronutrients of 10-12 years old subjects shows that over consumption of macronutrient was lower among MDM school subjects. Whereas in NMDM school subjects mean energy intake was $1726.5 \mathrm{kcal} / \mathrm{d}$, mean protein consumed was $23.2 \mathrm{~g} / \mathrm{d}$, mean carbohydrate intake $206.4 \mathrm{~g} / \mathrm{d}$ and mean fat intake $29.3 \mathrm{~g} / \mathrm{d}$.

However both the schools were not fulfilling the RDA for 10-12 years subjects. Significant difference in protein consumption was found, where protein was consumed in lower quantity among MDM school than in NMDM school $(\mathrm{t}=4.14$, $\mathrm{p}<0.05)$. MDM school subjects had lower intake of iron $(3.2 \pm 0.4)$ than non NMDM school subjects (Iron 4.77 \pm 1.14 ). Whereas mean zinc intake was found $(3.4 \pm 0.5)$ in NMDM school and in MDM school subject's was (4.14 \pm 0.64$)$ (Table 6).

Table: 1 Age wise distribution of study subjects

\begin{tabular}{|c|c|c|c|c|}
\hline \multirow[t]{3}{*}{ Age group } & \multicolumn{4}{|c|}{ Respondents } \\
\hline & \multicolumn{2}{|c|}{ Mid day meals $(n=50)$} & \multicolumn{2}{|c|}{ Non Mid day meals $(n=50)$} \\
\hline & $\mathrm{N}$ & $\%$ & $\mathrm{~N}$ & $\%$ \\
\hline $8-9$ years & 6 & 12.0 & 4 & 8.0 \\
\hline $9-10$ years & 6 & 12.0 & 12 & 24.0 \\
\hline 10-11 years & 11 & 22.0 & 7 & 14.0 \\
\hline 11-12 years & 27 & 54.0 & 27 & 54.0 \\
\hline
\end{tabular}


Int.J.Curr.Res.Aca.Rev.2016; 4(6): 61-67

Table: 2 Gender wise distribution of the respondents

\begin{tabular}{|c|c|c|c|c|}
\hline \multirow{2}{*}{ Gender } & \multicolumn{4}{|c|}{ Respondents } \\
\cline { 2 - 5 } & \multicolumn{2}{|c|}{$\begin{array}{c}\text { Mid day meals } \\
(\mathrm{n}=50)\end{array}$} & \multicolumn{2}{c|}{$\begin{array}{c}\text { Non mid day meals } \\
(\mathrm{n}=50)\end{array}$} \\
\cline { 2 - 5 } & $\mathrm{N}$ & $\%$ & $\mathrm{~N}$ & $\%$ \\
\hline Male & 18 & 36.0 & 32 & 64.0 \\
\hline Female & 32 & 64.0 & 18 & 32.0 \\
\hline
\end{tabular}

Table: 3 Anthropometry measurements (height-for-age) of the respondents

\begin{tabular}{|c|c|c|c|c|c|}
\hline \multirow{2}{*}{ Age group } & \multicolumn{4}{|c|}{ Height $(\mathrm{cm})$} & \multirow{2}{*}{ ' $\mathrm{t}$ ' test } \\
\cline { 2 - 5 } & \multicolumn{3}{|c|}{ Mid day meals $(\mathrm{n}=50)$} & Non Mid day meals $(\mathrm{n}=50)$ & \multirow{2}{*}{} \\
\cline { 2 - 5 } & Mean & SD & Mean & SD & \multirow{2}{*}{$1.35^{\text {NS }}$} \\
\hline 8 -9 years & 115.5 & 12.45 & 124.2 & 8.5 & $1.52^{\text {NS }}$ \\
\hline 9-10 years & 132.3 & 5.68 & 127.3 & 8.15 & $1.47^{\text {NS }}$ \\
\hline 10-11 years & 129.5 & 3.20 & 134.2 & 9.96 & $5.08^{*}$ \\
\hline $11-12$ years & 134.7 & 3.56 & 142.2 & 6.79 & \\
\hline
\end{tabular}

*Significant at $5 \%$ level, NS: Non significant, $\mathrm{t}(0.05,98 \mathrm{df})$

Table: 4 Anthropometry measurements (weight-for-age) of the respondents

\begin{tabular}{|c|c|c|c|c|c|}
\hline \multirow{2}{*}{ Age group } & \multicolumn{4}{|c|}{ Weight $(\mathrm{kg})$} & \multirow{2}{*}{ 't' Test } \\
\cline { 2 - 5 } & \multicolumn{3}{|c|}{ Mid day meals(n=50) } & Non Mid day meals(n=50) & \\
\cline { 2 - 5 } & Mean & SD & Mean & SD & \\
\hline 8 -9 years & 19 & 3.03 & 22.5 & 3.10 & $1.77^{\text {NS }}$ \\
\hline 9-10 years & 27.75 & 4.33 & 24.75 & 5.14 & $1.22^{\text {NS }}$ \\
\hline 10-11 years & 29.13 & 3.66 & 30.7 & 9.72 & $0.49^{\text {NS }}$ \\
\hline 11-12 years & 34.42 & 4.76 & 32.35 & 7.40 & $1.22^{\text {NS }}$ \\
\hline
\end{tabular}

NS: Non significant, $\mathrm{t}(0.05,98 \mathrm{df})$

Table: 5 Macronutrient and Micronutrient intake among the study subjects (8-10 years)

\begin{tabular}{|c|c|c|c|c|c|c|}
\hline \multirow{2}{*}{ Nutrients } & \multirow{2}{*}{ RDA* } & \multicolumn{2}{|l|}{ Mid day meal(n=50) } & \multicolumn{2}{l|}{ Non mid day meal(n=50) } & \multirow{2}{*}{ 't' test } \\
\cline { 3 - 6 } & & Mean & SD & Mean & SD & \\
\hline Energy (kcal) & 1690 & 1355 & 352.02 & 1682.2 & 314.7 & $2.80^{*}$ \\
\hline Protein $(\mathrm{g})$ & 29.5 & 18.1 & 3.20 & 24.7 & 3.3 & $5.83^{*}$ \\
\hline CHO $(\mathrm{g})$ & 253.5 & 172.1 & 39.94 & 197.3 & 29.8 & $2.043^{*}$ \\
\hline Fat $(\mathrm{g})$ & 30 & 29.9 & 4.6 & 29.6 & 2.9 & $0.222^{\mathrm{NS}}$ \\
\hline Iron (mg) & 21 & 3.57 & 0.55 & 4.81 & 1.12 & $5.29^{*}$ \\
\hline Zinc (mg) & 8 & 3.25 & 0.54 & 4.05 & 0.88 & $1.98^{\mathrm{NS}}$ \\
\hline
\end{tabular}


Int.J.Curr.Res.Aca.Rev.2016; 4(6): 61-67

Table: 6 Macronutrient and Micronutrient intake among the study subject (10-12 years)

\begin{tabular}{|c|c|c|c|c|c|c|}
\hline \multirow{2}{*}{ Nutrients } & \multirow{2}{*}{ RDA* $^{*}$} & \multicolumn{2}{|c|}{ Mid day meal(n=50) } & \multicolumn{2}{c|}{ Non mid day meal $(\mathrm{n}=50)$} & \multirow{2}{*}{ ' $\mathrm{t}$ ' test } \\
\cline { 3 - 6 } & & Mean & SD & Mean & SD & \\
\hline Energy (kcal) & 2190 & 1590.8 & 522.8 & 1726.5 & 337.3 & $1.266^{\text {NS }}$ \\
\hline Protein $(\mathrm{g})$ & 39.9 & 19.5 & 4.6 & 23.2 & 2.4 & $4.145^{*}$ \\
\hline CHO $(\mathrm{g})$ & 301.5 & 194.9 & 51.4 & 206.4 & 25.3 & $1.167^{\text {NS }}$ \\
\hline Fat $(\mathrm{g})$ & 35 & 27.5 & 6.4 & 29.3 & 4.1 & $4.1^{\text {NS }}$ \\
\hline Iron (mg) & 27 & 3.2 & 0.4 & 4.77 & 1.14 & $7.47^{*}$ \\
\hline Zinc $(\mathrm{mg})$ & 9 & 4.14 & 0.64 & 3.4 & 0.5 & $5.26^{*}$ \\
\hline
\end{tabular}

*Source- RDA for Indians, $2010 \quad$ *Significant at 5\% level, NS: Non significant

Figure: $1 \mathrm{BMI}$ of the study subjects

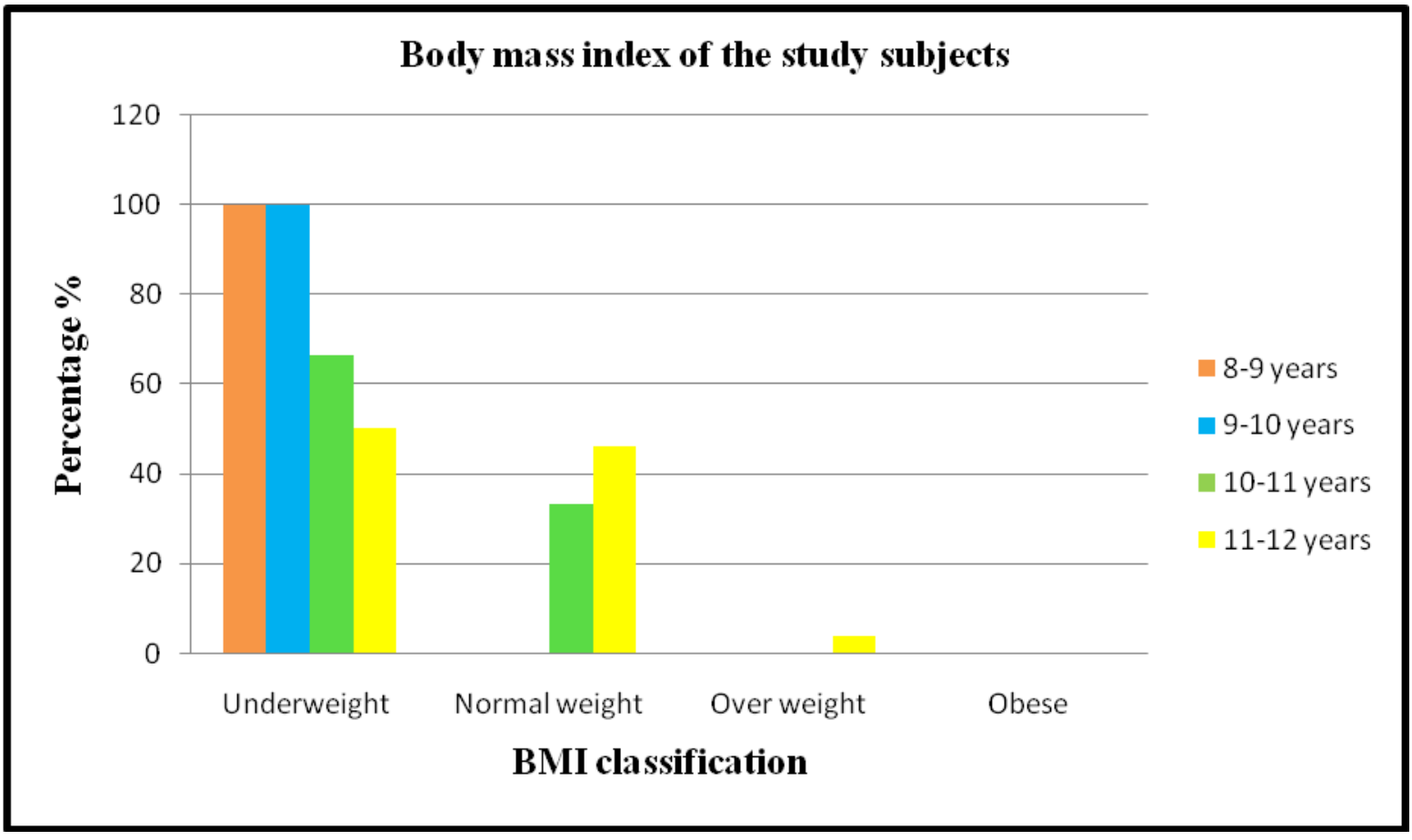

\section{Conclusion}

It can be therefore concluded that undernourishment of the subjects could be leading cause of zinc deficiency. The study subjects could also be at the risk of other nutrient deficiencies as observed through their 24 hours diet recall which shows low intake of energy, protein, carbohydrates, iron and zinc. Both the categories of age group (8-10 and 10-11 years) had low intakes of all macronutrients and micronutrients as compared to RDA. The consumption of fat was on the borderline as compared with RDA. In age group 8-10 years slightly higher zinc intake was found higher (4.05 \pm 0.88$)$ than $10-12$ years subject's belonging to NMDM school. 
The respondents were classified based on BMI-for-age percentile into different categories. The BMI results show that maximum mean height of $142.2 \pm 6.79$ for 11-12 years and minimum mean height being 124.2 \pm 2.5 for 8-9 years in NMDM school. Similar increasing trend was observed under MDM school subjects also, maximum mean height for 11-12 years was $134.7 \pm 3.56$ and minimum mean height for 8-9 years was $115.5 \pm 12.45$.

\section{Acknowledgement}

Head Masters, School teachers and students of both the schools.

\section{References}

Bharati, S., Chakrabarty, S., Som, S., Pal, M., Bharati, P. 2010. Socio-economic determinants of underweight children in West Bengal, India. Asian Pacific J. Trop. Med., 322-327.

Brown, K.H., Peerson, J.M., Rivera, J., Allen, L.H. 2006. Effect of supplemental zinc on the growth and serum zinc concentrations of prepubertal children: a meta-analysis of randomized controlled trials. The American J. Clin. Nutri., 75(6): 1062 1071.

Hippel, P.T., Powell, B., Downey, D.B., Rowland, N.J. 2007. The Effect of School on Overweight in Childhood: Gain in Body Mass Index During the School Year and During Summer Vacation. American J. Public Health, 97(4): 696-702. http://doi.org/10.2105/AJPH.2005.080754
Marasinghe, E., Chackrewarthy, S., Abeysena, C., Rajindrajith, S. 2015. Micronutrient status and its relationship with nutritional status in preschool children in urban Sri Lanka. http://repository.kln.ac.lk/handle/1234567 89/9126

Minj, C., Goud, B.R., James, D.E., Furruqh, F., Mohammad, A. 2014. Impact of School Mid Day Meal Program on the Nutritional status of Children in a rural area of South Karnataka, India. Int. J. Curr. Res. Acad. Rev., 2(8):78-84.

Nepal, A.K., Gelal, B., Mehta, K., Lamsal, M., Pokharel, P.K., Baral, N. 2014. Plasma zinc levels, anthropometric and sociodemographic characteristics of school children in eastern Nepal. BMC Research Notes, 7: 18. http://doi.org/10.1186/17560500-7-18

Shenkin, A. 2006. Micronutrients in health and disease. Postgraduate Med. J., 82(971), 559-567. http://doi.org/10.1136/pgmj.2006.047670

Wuehler, S.E., Sempértegui, F., Brown, K.H. 2008. Dose-response trial of prophylactic zinc supplements, with or without copper, in young Ecuadorian children at risk of zinc deficiency. The American J. Clin. Nutri., $\quad$ 87(3): $\quad 723-733$. www.who.int/growthref/who2007_bmi_f or_age/en/

Yu, Qin., Melse-Boonstra, A., Zhao, J., Wu, M., $\mathrm{Hu}$, X., Kok, F.J. 2009. Stunting and zinc deficiency among primary school children in rural areas with low soil zinc concentrations in Jiangsu Province, China. Asia Pacific J. Clin. Nutri., 18(1): 15-21.

\section{How to cite this article:}

Iram Khan and Sangeeta Pandey. 2016. Impact of Mid Day Meal on Nutritional Status of School Going Children with Special Emphasis on Zinc. Int.J.Curr.Res.Aca.Rev.4(6): 61-67. doi: http://dx.doi.org/10.20546/ijcrar.2016.406.007 